\title{
FAKTOR-FAKTOR YANG MEMPENGARUHI KEPATUHAN SUKARELA WAJIB PAJAK
}

\begin{abstract}
The aim of this research is finding factors affect voluntary compliance. These factors consist of tax knowledge, tax spent tranparency, and tax fairness. Samples of this reasearch are Personal Tax Payers who attend to submit monthly Tax Return at Jakarta Kebayoran Dua Tax Office. Results of this research are that tax knowledge of tax payers, tax spent tranparency, and tax fairness have significant effect toward voluntary compliance partially and together.
\end{abstract}

Keyword: tax compliance, tax knowledge, tax spent tranparency, fax fairness, personal tax payer

\section{PENDAHULUAN}

Self Assesment System (SAS) pajak di Indonesia dianggap sebagai reformasi besar dalam sistem pajak Indonesia tahun 1983, karena pada tahun sebelumnya menggunakan Official Assesment System (OAS). Dengan SAS yang melibatkan keaktifan Wajib Pajak dalam kewajiban perpajakannya, diharapkan akan menciptakan kesadaran dan kepatuhan yang lebih tinggi. Sistem yang baru tersebut berusaha menempatkan Wajib Pajak sebagai subjek bukan sebagai objek artinya Wajib Pajak dianggap sebagai motor keberhasilan SAS untuk itu hak-hak dan kewajiban mereka harus dihargai. Dan hal tersebut juga dibuktikan dari beberapa data dan penelitian yang menyebutkan dengan SAS menciptakan kesadaran dan kepatuhan pajak yang lebih tinggi hal tersebut terlihat pada data semakin bertambahnya jumlah pengumpulan pajak dan jumlah Wajib Pajak setiap tahunnya (Budiatmanto, 1999: Palil, 2005).

Kepatuhan Wajib Pajak dapat diartikan sebagai sikap Wajib Pajak dalam memenuhi kewajiban sesuai dengan Peraturan Perpajakan yang berlaku. Hal tersebut sangat dipengaruhi dengan motivasi, dan akhirnya motivasi tersebut akan menjadi sebuah sikap atau perilaku. Fronzoni (1999) kepatuhan memiliki arti sebagai (1) melaporkan dengan benar pajak, (2) menghitung kewwajiban dengan benar, (3) tepat waktu saat pengembalian, (4) tepat waktu saat menyetor.

Hal-hal yang dilakukan aparat pajak dalam meningkatkan kesadaran pajak secara sukarela adalah dengan banyak melakukan sosialisasi terkait dengan undang-undang perpajakan yang baru baik melalui sosial media, internet dan banner dengan masif. Jadi banyaknya sosialisasi akan menjadikan pengetahuan Wajib Pajak terhadap aturan perpajakan akan semakin baik, sehingga kepatuhan sukarela akan menjadi meningkat seiring dengan pengetahuan Wajib Pajak terkait dengan penggunaan uang pajak maupun peraturan bisa diterima dengan baik. Sehingga kepatuhan secara sukarela semakin tinggi pula bila pengetahuan terkait pajak juga baik.

Unsur lain yang dapat mempengaruhi kepatuhan Wajib Pajak secara sukarela adalah tentang transparansi belanja pajak yang telah dibayarkan Wajib Pajak terhadap negara. Transparansi belanja pajak juga harus mendokumentasikan alokasi yang jelas terhadap alokasi belanja negara yang berasal dari pajak. Transparansi 
belanja dari sektor pajak harus jelas dan berpihak pada kepentingan rakyat banyak, terlebih diprioritaskan untuk masyarakat yang sangat membutuhkan. Kesadaran sukarela masyarakat Amerika muncul pada saat pemerintah mempublikasi secara transparan belanja pajaknya (Jones, 2003). Machogu dan Amayi (2013) melakukan penelitian terhadap UMKM yang menghasilkan temuan bahwa pendidikan dan penyuluhan akan menjadikan usahawan menjadi patuh.

OECD, 2008 dalam Madugu, (2012) mencatat bahwa pemerintah, perpajakan dan akuntabilitas mengindikasikan pengakuan adanya perjanjian sosial pemajakan antara pemerintah dan rakyatnya. Artinya masyarakat akan menunaikan kewajiban perpajakannya apabila mereka memiliki hak untuk ikut menentukan kebijakan publik dan bagaimana belanja negara dibentuk. Dan di Amerika ada kata-kata yang sampai sekarang kita kenal yaitu "no taxation without representation".

Keadilan pajak atau Tax Fairness menjadi salah satu asas dalam memunculkan peraturan perpajakan, namun terkadang maksud keadilan dalam peraturan perpajakan yang dianggap sudah dilakukan oleh aparat dirasa belum mencukupi oleh masyarakat, khususnya Wajib Pajak. Misalnya penerapan pajak tidak langsung untuk pembayaran PPN, mereka yang akhirnya benar-benar memberikan uangnya untuk disumbangkan ke negara karena konsumsi yang ia lakukan adalah konsumen akhir, atau masyarakat bawah. Kemudian masalah beban pajak PBB atas tanah dan bangunan. Variabel tanah dihitung berdasarkan pada Nilai Jual Objek Pajak (NJOP) yang penghitungannya dianggap kurang tepat karena tidak memenuhi melihat unsur mampu atau tidak secara ekonomi, mahalnya beban PBB untuk kelas tanah, kelas A (biasanya untuk tanah dan bangunan di tengah kota), beban untuk kelas ini tinggi. Dari regulasi yang ada pada bidang tersebut seakan-akan memberikan paradigma bahwa hanya orang mampulah yang layak memiliki tanah dan bangunan di kota, mereka yang miskin tidak akan sanggup membayar tipe kelas A tersebut. Ada juga realita ketidakadilan yang sering kita dengar, baca dan lihat. Penjudi kelas kakap, mereka tidak dikenakan pajak atas hasil judi mereka. Menurut Harahap (2004) ketidakadilan menimbulkan sikap tidak patuh (non compliance) terhadap pajak.

Musgrave menyatakan bahwa perpajakan mengacu pada kemampuan seseorang untuk membayar pajak, seharusnya sejajar dengan kapasitas membayar yang sama, sehingga seseorang dengan kemampuan yang lebih besar seharusnya membayar yang lebih besar pula (James dan Nobes, 1992). Cristian et.al. dalam Schisler, (1995) menemukan bahwa persepsi keadilan pajak memiliki hubungan yang positif dengan beberapa langkah dalam tingkatan kepatuhan.

Penelitian yang dilakukan oleh Rahayu pada tahun 2005 terkait dengan kepatuhan (sebagai variabel dependen) dan pengetahuan terkait pajak oleh Wajib Pajak, transparansi pelaporan belanja pajak, serta keadilan pajak (sebagai variabel independen) yang menggunakan sampel 200 Wajib Pajak Badan pada KPP Pratama Surakarta. Hasilnya bahwa secara parsial dan bersama-sama pengetahuan Wajib Pajak, transparansi belanja Pajak serta keadilan pajak memiliki pengaruh signifikan terhadap kepatuhan pajak. Dari penelitian di atas peneliti mencoba meneliti kembali (replikasi) dengan sampel Wajib Pajak orang pribadi pada KPP Pratama Jakarta Kebayoran II. Pengetahuan pajak yang lebih baik, transparansi belanja negara dan keadilan pajak yang lebih baik akan memiliki kesadaran pajak yang lebih baik pula, karena ketiga variabel di atas adalah variabel yang bisa menumbuhkan kesadaran sukarela Wajib Pajak untuk patuh terhadap perundang-undangan dan 
peraturan pajak. Tujuan penelitian ini adalah untuk mengetahui: (1) Apakah semakin baik pengetahuan Wajib Pajak tentang peraturan perpajakan akan semakin tinggi pula kepatuhan Wajib Pajak baik di KPP Pratama Jakarta Kebayoran II; (2) Apakah dengan semakin transparan belanja negara akan meningkatkan kepatuhan Wajib Pajak baik di KPP Pratama Jakarta Kebayoran II. (3) Apakah dengan semakin adil pajak akan meningkatkan kepatuhan Wajib Pajak baik di KPP Pratama Jakarta Kebayoran II.

\section{KERANGKA PEMIKIRAN TEORITIS DAN PENGEMBANGAN HIPOTESIS}

Kepatuhan Wajib Pajak adalah bagaimana melihat sejauh mana Wajib Pajak mengikuti undang-undang dan peraturan yang berlaku dalam melaporkan pajak. Gibson dalam Mayer, (2003) sebagaimana dikutip Kepatuhan Wajib Pajak dapat juga diartikan sebagai tingkat sejauh mana Wajib Pajak mencatat semua tax return secara tepat waktu dan melaporkan utang pajaknya secara akurat berdasarkan undang-undang dan peraturan yang berlaku. Sedangkan menurut Franzoni (1999) kepatuhan diartikan sebagai (1) melaporkan dengan benar pajak, (2) memperhitungkan dengan benar, (3) tepat waktu pelaporan, (4) tepat waktu menyetorkan pajak yang telah dihitung. Dan Alm dalam Palil (2005) kepatuhan didefinisikan sebagai pelaporan semua pendapatan dan pembayaran pajak secara keseluruhan yang sesuai dengan aplikasi hukum, peraturan dan keputusan hakim.

Mardiasmo (2002) memberikan pengertian transparansi sebagai upaya semaksimal mungkin agar seluruh kebijakan pemerintah selalu dapat diinformasikan kepada masyarakat. Pemerintah harus sedapat mungkin memberikan informasi yang dibutuhkan masyarakat, termasuk dalam hal ini adalah terkait dengan penggunaan belanja negara yang berasal dari pajak dan fasilitas apa yang telah diberikan dalam hal perpajakan, sehingga masyarakat merasa apa yang dibauarkan melalui pajak juga akan kembali dirasakan karena pengeluaran uang negara dilakukan untuk kepentingan masyarakat.

Pengetahuan masyarakat terhadap belanja publik dan partisipasi masyarakat dalam menentukan anggaran belanja negara dapat mempengaruhi kepatuhan masyarakat. Beberapa pemerintah daerah atau beberapa negara yang menerapkan hal tersebut salah satu diantaranya adalah di kota Seattle, Redmond dan Kennewick Washington, sangat mudah dipahami dan sangat mudah diakses Laporan Anggaran Pendapatan dan Belanja terkait fasilitas. Di Los Angeles (California) belanja pemerintah harian (Major's Budget Day) mampu menunjukkan kepada masyarakat apa kontribusi yang bisa diberikan dan pengembangan kebijakan apa yang bisa memecahkan masalah pemerintah. Sehingga partisipasi masyarakat cukup tinggi dan kepatuhan wajib pajakpun tinggi. Dan Penelitian Pommerehne and Weck-Hannemann; Feld and Frey; dan Torgler dalam Djawadi and Fahr (2013) menyebutkan bahwa pemerintah Swiss mengalami peningkatan kepatuhan Wajib Pajak disebabkan oleh adanya partisipasi warga masyarakat dalam pembuatan anggaran negara.

\section{H1: Adanya transparansi belanja keuangan negara akan menyebabkan meningkatnya kepatuhan sukarela Wajib Pajak.}

Penelitian yang dilakukan oleh Modugu (2012) terhadap negara di Nigeria menyebutkan bahwa variabelvariabel bebas terkait akuntabilitas yaitu keadilan pajak, treatment otoritas pajak, persepsi masyarakat terhadap pemerintah, tingkat persepsi akuntabilitas pemerintah, tingginya tarif pajak, provisi belanja 
publik, adanya kemungkinan deteksi dan sangsi, kekuatan partai politik, religiusitas, kemudahan memahami aturan pajak, etika dan moral, kepuasan masyarakat terhadap pemerintah, dan prilaku positif terhadap kesadaran pajak oleh masyarakat sekitar. Dengan variabel dependen tingkat kesadaran pajak sukarela, dan menghasilkan kesimpulan bahwa semua variabel tersebut signifikan mempengaruhi kesadaran pajak sukarela kecuali, variabel tingginya tarif, adanya deteksi dan sangsi, religiusitas dan pengawasan kesadaran pajak oleh masyarakat sekitar. Penelitian yang dilakukan Djawadi dan Fahr (2013) di Jerman, menghasilkan temuan bahwa akuntabilitas dan transparansi belanja sangat mempengaruhi kesadaran pajak sukarela. Transparansi menggunakan konstruk penyediaan informasi perpajakan oleh otoritas pajak, penggunaanbudget keu angan negara bagian, bagaimana alokasi belanja dari sektor pajak dikembalikan masyarakat dalam bentuk belanja publik.

Keadilan pajak dikriteriakan oleh Musgrave dan Musgrave (1984) sebagai: 1) Pendekatan kemanfaatannya artinya keadilan sebagai kontribusi yang diberikan oleh masing-masing Wajib Pajak dihubungkan terhadap manfaat yang mereka peroleh dari pelayanan publik. Aplikasi dari prinsip manfaat diantaranya adalah dengan adanya manfaat secara umum dari pajak, manfaat spesifik dari pajak, pembebanan yang dikenakan, dan keuntungan yang diperoleh. 2) Pendekatan kemampuan membayar (Ability to Pay), maksudnya pendekatan ini mendasarkan pajak pada berapa pendapatan yang diperoleh dan seberapa tingkat konsumsi seseorang, sehingga menyebabkan dia dikenai pajak. Hal ini berartijuga melihat bagaimana kondisi kemampuan seseorang yang dikenai pajak. Pendekatan kemampuan bayar ini juga memperhatikan tingkat kesejahteraan seseorang dalam kaitannya dengan kewajiban perpajakannya. 3) Kemampuan Bayar dan Keadilan Vertikal. Dalam hal ini Wajib Pajak akan merasa diperlakukan adil apabila pajak yang mereka bayarkan sama dalam pengorbanan dan hilangnya kesejahteraan (pendapatan). Intinya pajak yang mereka bayarkan harus memperhatikan keadilan dalam masalah berapa uang yang dikeluarkan dan kompensasi kesejahteraan yang didapat.

Palil (2005) meneliti terkait pengetahuan Wajib Pajak, dan mendapatkan hasil bahwa pengetahuan yang baik tentang pajak akan mengurasi penyelewengan pajak (tax evasion). Hal yang sama jua ditemukan oleh Kassipillai; Song dan Yarbourgh, dalam Palil (2005), yang menyatakan bahwa pengetahuan tentang pajak merupakan hal yang sangat penting bagi berjalannya Self assessment system, yang akhirnya pengetahuan pajak akan mempengaruhi sikap Wajib Pajak.

Kassipilai dalam Palil (2005), menyebutkan bahwa pengetahuan pajak akan bertambah seiring dengan masa pendidikan yang dilakukan dan kursus, walaupun secara tidak langsung tidak ditemukan adanya kaitan dengan sikap Wajib Pajak terhadap pengetahuan. Akan tetapi Song dan Yarbrough (1978) dalam hasil penelitiannya mengemukakan bahwa semakin tinggi pengetahuan pajak maka semakin tinggi juga nilai etika terhadap pajak. Robert et. Al. dalam Palil (2005) menyatakan bahwa pengetahuan tentang peratuan pajak akan mempengaruhi tax fairness. Dan pada studi yang dilakukan oleh Schisler (1995) bahwa tingkat pendidikan Wajib Pajak khususnya mengenai sistem pajak mempengaruhi kepatuhan pajak.

\section{H2: Semakin memadai pengetahuan Wajib Pajak tentang perundang-undangan pajak maka semakin tinggi pula kepatuhan sukarela Wajib Pajak}


Supriyanto (2004) mencoba mendekatkan kaitan anatara demokratisasi dan kepatuhan Wajib Pajak di era Reformasi tahun 1998, dalam penelitian tersebut berusaha memasukkan variabel-variabel seperti pemahaman demokrasi, akuntabilitas publik, transparansi publik, kebebasan berusaha, kebebasan berpartisipasi dan berorganisasi politik, pada kondisi full informed, pemahaman terhadap undang-undang dan variabel intervening yang digunakan adalah persepsi masyarakat tentang pajak, dan variabel dependennya adalah partisipasi Wajib Pajak memenuhi kewajibannya (kepatuhan). Dari hasil penelitian didapatkan bahwa variabel akuntabilitas, transparansi, kondisi full informed dan persepsi Wajib Pajak tentang pajak memiliki hubungan yang signifikan terhadap kepatuhan.

Musgrave (1989) menyatakan bahwa perpajakan mengacu pada kemampuan seseorang untuk membayar pajak harus sejajar dengan kapasitas membayar yang sama dan seseorang dengan kemampuan yang lebih besar seharusnya membayar yang lebih besar pula. Cristian et.al. dan Roth et.al. dalam Schisler, (1995) menyatakan juga bahwa keadilan memiliki peran yang penting dalam kepatuhan pajak serta menemukan bahwa persepsi keadilan pajak memiliki hubungan yang positif dengan beberapa langkah dalam tingkatan kepatuhan.

\section{H3: Adanya keadilan pajak menyebabkan meningkatnya kepatuhan sukarela Wajib Pajak.}

\section{HASIL DAN PEMBAHASAN}

Penelitian dilakukan dengan menyebarkan seluruh kuesioner kepada responden yang memenuhi kriteria penelitian. Kuesioner diberikan kepada 150 Wajib Pajak yang terdiri dari 101 Wajib Pajak Orang Pribadi (WPOP) dan mengisi dengan lengkap, 49 responden menolak mengisi kuisioner.

\section{Uji Pengaruh Variabel Independen terhadap Variabel Dependen}

Dengan memakai $a=5 \%$, maka hasil analisis regresi dari program SPSS setelah dilakukan uji asumsi klasik adalah disajikan pada tabel Ringkasan Hasil Analisis Regresi.

Pada tabel tersebut maka dapat disimpulan bahwa, dari ketiga variabel independen yang yang diuji menggunakan uji regresi bernilai signifikan. Hal itu dapat dilihat dari signifikansi yang ada secara berturut-turut terkait variabel pengetahuan, transparansi dan keadilan bernilai 0,020,0,016, dan 0,017, dimana ketiganya memiliki nilai yang lebih rendah dari 0,05 (PV). Atau Pengetahuan Perpajakan, dengan tingkat keyakinan 95\%, diperoleh $\mathrm{t}$ tabel 1,980 dan t hitung sebesar 2,360. maka dapat disimpulkan bahwa $\mathrm{t}$ hitung $>\mathrm{t}$ tabel, jadi $\mathrm{H}_{\mathrm{a} 1}$ diterima atau $\mathrm{H}_{0}$ ditolak. Berikutnya adalah terkait variabel transparansi belanja negara, diperoleh $\mathrm{t}$ tabel 1,980 dan t hitung sebesar 2,448, maka dapat disimpulkan bahwa t hitung $>\mathrm{t}$ tabel, jadi $\mathrm{H}_{\mathrm{a} 2}$ diterima atau $\mathrm{H}_{02}$ ditolak. Varibel terakhir adalah keadilan pajak, diperoleh $\mathrm{t}$ tabel 1,980 dan $\mathrm{t}$ hitung sebesar 2,436 maka $\mathrm{t}$ hitung $>\mathrm{t}$ tabel, jadi $\mathrm{H}_{\mathrm{a} 3}$ diterima atau $\mathrm{H}_{03}$ ditolak.

\section{Uji Global (Global Test) atau Uji Koefisien Regresi Serentak (Uji F)}

Dari tabel di atas akan didapatkan kesimpulan bahwa pada $a=5 \%, F=7,837$ dengan nilai sinifikansi 0,000, maka nilai signifikansi $\mathrm{F}$ kurang dari 0,05 sehingga dapat disimpulkan bahwa pada $\mathrm{a}=5 \% \mathrm{H}_{0}$ ditolak. 
Asumsinya adalah secara bersama-sama ketiga variabel independen di atas mempengaruhi kepatuhan sukarela Wajib Pajak.

Pada tabel di atas juga didapatkan informasi bahwa nilai koefisien korelasi (R) sebesar 44,2\% dan Adjusted R Square dengan nilai 19,5\%. Maka dengan demikian, dapat diambil kesimpulan bahwa model penelitian ini lebih banyak dipengaruhi faktor di luar penelitian yaitu sebesar 80,5\%. Dan hanya 19,5\% dapat dijelaskan dengan variabel yang diteliti.

\section{KESIMPULAN, KETERBATASAN DAN IMPLIKASI}

\section{Kesimpulan}

Berdasarkan analisis hasil penelitian yang telah dikemukakan pada bab terdahulu dapat disimpulkan bahwa:

1. Pengetahuan Wajib Pajak, memiliki pengaruh terhadap kepatuhan sukarela Wajib Pajak. Hal ini menunjukkan bahwa semakin tinggi pemahaman pajak wajib pajak maka tingkat kepatuhannya akan meningkat.

2. Transparansi belanja Negara memiliki pengaruh terhadap kepatuhan sukarela Wajib Pajak. Artinya bahwa semakin tinggi tingkat transparansi pemakaian dana pajak maka akan meningkatkan kepatuhan wajib pajak.

3. Keadilan pajak memiliki pengaruh terhadap kepatuhan sukarela Wajib Pajak. Ini menunjukkan bahwa keadilan pajak dapat meningkatkan kepatuhan wajib pajak.

\section{Keterbatasan Penelitian}

Dalam melakukan penelitian ini, penulis menyadari keterbatasan yang ada pada penelitian ini. Diantaranya adalah:

1. Penelitian ini mungkin hanya bisa mengukur tingkat kepatuhan Wajib Pajak yang berada pada wilayah KPP Jakarta Kebayoran II dan belum tentu mampu mewakili wilayah lain.

2. Penelitian ini hanya terdiri dari 3 variabel independen yang memiliki nilai $R^{2}$ yang terlalu kecil, sehingga belum bisa menjelaskan secara kuat bahwa variabel independen mampu mempengaruhi secara kuat variabel kepatuhan Wajib Pajak.

\section{Implikasi Penelitian}

Implikasi penelitian ini terhadap penelitian selanjutnya dapat disajikan sebagai berikut :

1. Berdasarkan model yang diperoleh dari penelitian ini maka untuk penelitian selajutnya dapat dilakukan dengan cara menambahkan variable lain.

2. Penelitian selanjutnya dapat memeprluas obyek penelitian sehingga dapat dipeoleh sampel yang lebih banyak sehingga dapat memwakili populasi penelitian. 


\section{DAFTAR PUSTAKA}

Budiatmanto, Agus., (1999), Study Evaluasi Kepatuhan Wajib Pajak Sebelum dan Sesudah Reformasi Perpajakan Tahun 1983 Studi Kasus pada Kantor Wilayah VIII Direktorat Jenderal Pajak Jawa Tengah dan Daerah Istimewa Yogyakarta. Unpublished Tesis. Yogyakarta: Universitas Gadjah Mada.

Davis, Jon S., Hecht, Gary dan Perkins, Jon D. (2003), Social Behaviors, Enforcement, and Tax Compliance

Dynamics. The Accounting Review. Januari, Vol 78,1. hal. 39-69.

Djawadi, Behnud M dan Fahr, Rene, (2013), The Impact Of Tax Knowledge ang Budget Spending Influence on

Tax Compliance. February Discussion Paper No 7255. IZA University Of Paderborn. Germany.

Franzoni, A. Luigi. (1999), Tax Evasion and Tax Compliance. University of Bologna, Italy.

Hartono, J. (2004), Metodologi Penelitian Bisnis: Salah Kaprah dan Pengalaman-pengalaman. Yogyakata: BPFE. Harahap, A. Asri, (2004), Paradigma Baru Perpajakan Indonesia. Jakarta: Integrita Dinamika Press,.

James. Simon dan Nobes, Christhoper. (1992), The Economisc of Taxation. Fourth Edition. America: Prentice Hall,. Jones, Sally M. (2003), Principles of Taxasion : for Bussiness and Investment Palnning. New York: McGraw-Hill. Machogu C.G dan Amayi Jairus B, (2013), The Effect of Tax Payer Education on Voluntary Tax Compliance,

Among SMES in Mwanza City Tanzania. International Journal of Marketing, Financial Service \& Mangement Reaseach. August, Vol 2 No 8.

Mardiasmo. (2002), Akuntansi Sektor Publik. Yogyakarta: Andi Offset,.

Mason, Robert D. dan Douglas A. Lind, (1999). Teknik Statistik untuk Bisnis dan Ekonomi. Edisi Kesembilan. Terjemahan Widyono Soetjipto, dkk. Jakarta: Penerbit Erlangga,.

Mayer, Marda Br. S. (2003), Pemeriksaan Pajak sebagai Tindakan Pengawasan atas Pelaksanaan Sistem Self Assessment dan Tingkat Kepatuhan Wajib Pajak (Studi Kasus: KPP Medan Timur). Unpublished Skripsi. Yogyakarta: Universitas Gadjah Mada.

Modugu, Prince Kennedy, (2012), Goverment Accountability and Voluntary Tax Compliance. Research Journal of Finance and Accounting, ISSN 2222-1697, Vol 3, No.5, ,

Munawir, S., (1982), Pokok-pokok Perpajakan. Edisi Kedua. Yogyakarta: Liberti.

Musgrave, Richard A. dan Musgrave, Peggy A1989. Public Finance in Theory and Practice. Fifht. New York: McGraw-Hill,.

Palil, M Rizal. Does Tax Knowledge Matter IN Self Assessment System? Evidence from Malaysia Tax Administrative.

The Journal of American Academy of Bussiness. Cambrige. No. 2. Maret, 2005.

, Surat Edaran Direktur Jenderal Pajak Nomor SE-13/PJ.331/2003 tentang Tata Cara Penentuan

Wajib Pajak Patuh yang Dapat Diberikan Pengembalian Pendahuluan Kelebihan Pembayaran Pajak. , Surat Edaran Direktur Jenderal Pajak Nomor SE-05/PJ.7/2004 Aktivitas Pendukung Pemeriksaan.

Punch, Keith F. Survey Research: The Basic. London: Sage Publication, 2003.

Santoso, Singgih. Buku Latihan SPSS Statistik Parametrik. Jakarta: Elex Media Komputindo, 2002.

Schisler, Dan L. Equity, Aggressiveness, Consensus: A Comparison of Tax Payers and Tax Preparers. Accounting Horizons. Vol 9. No 4. Desember. Hal. 76-87, 1995. 
Siahaan, Fadjar OP. The Influence of Tax Fairness ang Communicatioan on Voluntary Compliance: Trust as an Intervening Variable. Internasional Jurnal of Bussiness Vol 3 No 21. November 2012

Song Y.D. da T.E. Yarbrough, Tax Etics and Tax Attitude: A Survey Public. Administrations Review 28(5). 442-452, 1978.

Supriyanto, Agus. Partisipasi Wajib Pajak sebagai Barometer Kekuatan Negara Demokrasi: Studi empiris Persepsi Masyarakat Wajib Pajak dan Evaluasi Partisipasi Wajib Pajak Sebelum dan Sesudah Reformasi Tahun 1998. Unpublished Skripsi. Yogyakarta: Universitas Gadjah Mada, 2004.

Jurnal Akuntansi Indonesia 


\section{LAMPIRAN}

TABEL Ringkasan Hasil Analisis Regresi

\begin{tabular}{|lllll}
\hline Variabel & $\begin{array}{l}\text { Ko e f i s i e } \\
\text { Regresi (Beta) }\end{array}$ & $\mathrm{t}$ & Signifikansi & Keterangan \\
\hline Konstanta & 1,016 & 3,222 & 0,002 & \\
\hline Pengetahuan pajak & 0,150 & 2,360 & 0,020 & Signifikan \\
\hline Transparansi belanja pajak & 0,211 & 2,448 & 0,016 & Signifikan \\
\hline Keadilan pajak & 0,283 & 2,436 & 0,017 & Signifikan \\
\hline
\end{tabular}

$a=5 \% \quad \mathbf{F}=7,837(.000) \quad R=44,2 \% \mathbf{R}^{2}=19,5 \%$

Sumber: SPPS, Diolah 